\title{
USPOREDBA KVALITETE ŽIVOTA I PSIHIČKIH SIMPTOMA U ONKOLOŠKIH PACIJENATA LIJEČENIH KEMOTERAPIJOM I ZRAČENJEM
}

\author{
Maria Bačić, Dragan Babić, Marko Pavlović \\ Fakultet zdravstvenih studija, Sveučilište u Mostaru, Bosna i Hercegovina \\ Rad je primljen 2.2.2018. Rad je recenziran 1.4.2018. Rad je prihvaćen 9.4.2018.
}

\section{SAŽETAK}

UVOD: Rak je bolest koja zbog svoje težine i ozbiljnosti može imati snažan utjecaj na psihičko stanje bolesnika. Unatoč velikim iskoracima u liječenju malignih bolesti, tijek bolesti, liječenje i psihološki izazovi negativno utječu na kvalitetu života.

CILJ ISTRAŽIVANJA: Cilj ovog istraživanja bio je utvrditi kvalitetu života i profil psihičkih simptoma u onkoloških bolesnika te utvrditi razlikuje li se kvaliteta života i profil psihičkih simptoma između onkoloških bolesnika liječenih kemoterapijom i onkoloških bolesnika liječenih zračenjem.

ISPITANICI I POSTUPCI: Istraživanje je provedeno u Klinici za onkologiju Sveučilišne kliničke bolnice Mostar.Ispitivani uzorak tvorilo je 60 bolesnika koji su na provedbi kemoterapijskog i radioterapijskog liječenja. Za mjerenje kvalitete života koristio se Upitnik kvalitete života Svjetske zdravstvene organizacije (SZO) WHOQOL-BREF ljestvica. Za procjenu psihičkih simptoma koristila se Ljestvica samoprocjene SCL-90.

REZULTATI: U 63,3 \% slučajeva radilo se o muškarcima, te u 36,7 \% slučajeva o ženama. Najmlađi ispitanik imao je 27 a najstariji 77 godina. Bolesnici liječeni zračenjem statistički značajno većom ocjenom procjenjivali su svoje zadovoljstvo zdravljem u odnosu na bolesnike liječene kemoterapijom ( $\mathrm{p}=0,007)$. Onkološki bolesnici muškog spola liječeni zračenjem statistički značajno većom ocjenom procjenjivali su svoju kvalitetu života $(\mathrm{p}=0,037)$. Bolesnici s pozitivnim bračnim statusom liječeni zračenjem značajno većom ocjenom procjenjivali su svoje zadovoljstvo zdravljem ( $\mathrm{p}=0,019)$. Bolesnici liječeni kemoterapijom pokazali su statistički značajno veću izraženost simptoma somatizacije ( $p=0,037)$, interpersonalne vulnerabilnosti $(p<0,05)$, fobije $(p<0,05)$ i nespecifičnih simptoma $(p<0,05)$ u odnosu na bolesnike liječene zračenjem.

ZAKLJUČAK: Onkološki bolesnici liječeni zračenjem statistički značajno većom ocjenom procjenjivali su svoje zadovoljstvo zdravljem i imali su manju učestalost psihičkih simptoma u odnosu na bolesnike liječene kemoterapijom.

Kljuične riječi: kvaliteta života, psihički simptomi, onkološki pacijenti

Kontakt za razmjenu informacija: Maria Bačić

E-adresa; maria.bacic1993@gmail.com

\section{UVOD}

Rak je bolest koja zbog svoje težine i ozbiljnosti može imati snažan utjecaj na psihičko stanje bolesnika (1). Unatoč velikim iskoracima u liječenju malignih bolesti, tijek bolesti, liječenje i psihološki izazovi negativno utječu na kvalitetu života (KŽ) (2). Zdravstveni status važan je element KŽ. Jedan od indikatora zdravstvenog statusa jest samoprocjena zdravlja (3). Primanje same dijagnoze maligne bolesti je stresno. Osim prekomjernog fizičkog stresa uzrokovanog zbog bolesti i njenog liječenja mnogi pacijenti iskuse psihološki stres i brigu o dijagnozi i prognozi, zahtijevajućim tretmanima, odlukama o liječenju i prekidu uobičajenih životnih funkcija i uloga.

Jedan od ciljeva medicine koji tradicionalno dominiraju pri liječenju jest produljenje života. Kako 
su uspjesi u tom smjeru sve veći, postaje jasno da je takav cilj nedostatan. Medicina mora nastojati ne samo dodati godine života već pomoći da se tim dodanim godinama osigura KŽ koja će biti prihvatljiva i dostojna čovjeka (4). Ljudi koji žive s malignom bolesti imaju veći rizik za razvoj različitih psihičkih problema. Istraživanja pokazuju da takvi bolesnici pate ne samo od fizičkih simptoma bolesti, nego i od psihološkog i društvenog stresa koji je povezan s dijagnozom. Istraživanja govore da se osim straha od umiranja, pacijenti osjećaju ugroženi intervencijama, poput kemo ili radio-terapije, brinu o gubljenju njihova tjelesnog integriteta, neovisnosti i društvenih uloga (5). Znatan napredak postignut je u otkrivanju i liječenju raka. Rezultat je povećanje životnog vijeka pa se za mnoge pogođene pojedince vodi kao kronična bolest. Cilj ovog istraživanja bio je utvrditi KŽ i profil psihičkih simptoma u onkoloških bolesnika kao i razlikuje li se profil psihičkih simptoma i KŽ između onkoloških bolesnika liječenih kemoterapijom i onkoloških bolesnika liječenih zračenjem.

\section{ISPITANICI I METODE}

Istraživanje je provedeno u Klinici za onkologiju Sveučilišne kliničke bolnice Mostar u razdoblju od 12. svibnja do 30. rujna 2017. godine. Ispitivani uzorak tvorilo je 60 bolesnika koji su na provedbi kemoterapijskog i radioterapijskog liječenja. Najmlađi ispitanik imao je 27, dok je najstariji imao 77 godina. Iz studije su isključeni bolesnici u terminalnoj fazi bolesti.

Prvu skupinu tvorilo je 30 bolesnika koji su podvrgnuti samo radioterapijskom liječenju, dok je drugu skupinu tvorilo 30 bolesnika koji su u svom liječenju podvrgnuti samo kemoterapiji.

Izlazni parametri istraživanja bili su spol i dob ispitanika te njihov bračni status. Skupine su bile usporedive po sociodemografskim parametrima.

Za mjerenje KŽ koristio se Upitnik KŽ Svjetske zdravstvene organizacije (SZO) WHOQOL-BREF ljestvica (6). To je višestruko validirana, multidimenzionalna ljestvica koja dobro prepoznaje KŽ kod različitih skupina ispitanika. Koristi se u situacijama kada je ograničeno vrijeme ispitivanja, a samim time je i smanjeno opterećenje ispitanika. Fokusira se na 4 glavna područja unutar KŽ: tjelesno, psihičko zdravlje, socijalne odnose i okruženje. Upitnik u cijelosti sadrži 26 čestica. Rezultati domena dobivaju se kombinacijom 24 čestice upitnika. Rezultat u svakoj domeni izražava se kao prosjek odgovora na česticama koje je opisuju. Čestica opće KŽ i općeg zdravlja razmatraju se zasebno. Odgovori za svaku česticu daju se na ljestvici Lickertovog tipa od 1 do 5 , gdje 1 označava najmanje slaganje sa pojedinom česticom, a 5 označava najveće slaganje s česticom. Odgovori su transformirani na ljestvicu od 0-100. U upitniku se postavlja vremenski okvir od dva tjedna unutar kojeg sudionik procjenjuje KŽ. Rezultati domena izražavaju se u pozitivnom smjeru, odnosno viši rezultat pretpostavlja veću KŽ. Upitnik je kratak i potrebno je svega nekoliko minuta za njegovo ispunjavanje.

Za procjenu psihičkih simptoma koristila se Ljestvica samoprocjene SCL-90 (engl. Symptom Checklist-90). Ljestvica samoprocjene SCL-90 predstavlja provjeren mjerni instrument za procjenu psihičkih simptoma koji su posljedica djelovanja stresa (7).

Ljestvica se sastoji od 90 pitanja na koja ispitanik odgovara tako da procjenjuje na ljestvici od pet stupnjeva (od 0 - uopće ne do 4 - izrazito) razinu nelagode koju je u njemu pobudio opisani simptom. SCL-90-R ljestvica definirana je za mjerenje devet primarnih dimenzija simptoma i tri globalna indeksa stresa. Individualni rezultati dobiveni na ljestvici SCL-90-R izračunaju se na sljedeći način: za svaku se dimenziju izračuna "vrijednost intenziteta nelagode" tako što se zbroje vrijednosti svih odgovora za pojedinu dimenziju i podijele s brojem odgovora. Iz vrijednosti pojedinih dimenzija računaju se tri indeksa skale. Primarne dimenzije simptoma stresa su: somatizacija, opsesivna kompulzivnost, osjetljivost u međuljudskim odnosima, depresija, anksioznost, agresivnost, fobičnost, paranoidne ideje, psihotična obilježja i nespecifični simptomi.

Distribucija vjerojatnosti kvantitativnih varijabli testirana je na normalnost Smirnov-Kolmogorovljevim testom. Za prikaz srednje vrijednosti i mjere raspršenja koristila se aritmetička sredina $(\mathrm{M})$ i standardna devijacija (SD), a rezultati su testirani t-testom za nezavisne uzorke i Spearmanovim testom 
korelacije rangova. Dobivene statističke razlike prihvaćene su kao statistički značajne za $p<0,05$. $\mathrm{Za}$ statističku analizu dobivenih podataka rabio se programski sustav SPSS for Windows (inačica 13.0, SPSS Inc, Chicago, Illinois, SAD) i Microsoft Excell (inačica Office 2007, Microsoft Corporation, Redmond, WA, SAD).

\section{REZULTATI}

Istraživanjem je obuhvaćeno je ukupno 60 bolesnika s malignim bolestima liječenih na Klinici za onkologiju Sveučilišne kliničke bolnice Mostar u razdoblju 2017. godine. U 38 (63,3 \%) slučajeva radilo se o muškarcima, te u $22(36,7 \%)$ slučajeva o ženama. Najmlađi ispitanik ima je 27, dok najstariji ispitanik imao 77 godina. Prosječna dob ispitanika bila je 54,5 $\pm 12,0$ godina. Ukupno $43(71,6 \%)$ ispitanika ima pozitivan bračni status dok 17 (28,4 \%) ispitanika navodi da ne živi u bračnoj zajednici.

Procjena kvalitete života i zadovoljstva zdravljem mjerena upitnikom WHOQOL-BREF

Usporedbom ocjene KŽ među ispitivanim skupinama nije se pokazala statistički značajna razlika. Ocjena zadovoljstva zdravljem pokazala je značajnu razliku. Bolesnici liječeni zračenjem statistički značajno većom ocjenom procjenjivali su svoje zadovoljstvo zdravljem u odnosu na bolesnike liječene kemoterapijom $(\mathrm{p}=0,007)$ (tablica 1$)$.

Tablica 1. Rezultati i prosječne vrijednosti ocjene $K Z \check{Z} i$ zadovoljstva zdravljem u onkoloških bolesnika, postignuti u upitniku WHOQOL-BREF

\begin{tabular}{|c|c|c|c|c|c|c|}
\hline \multirow{3}{*}{ Domena } & \multicolumn{4}{|c|}{ Onkološki bolesnici } & \multirow{3}{*}{ t-test } & \multirow{3}{*}{$\mathrm{p}$} \\
\hline & \multicolumn{2}{|c|}{$\begin{array}{c}\text { Liječeni } \\
\text { kemoterapijom }\end{array}$} & \multicolumn{2}{|c|}{$\begin{array}{c}\text { Liječeni } \\
\text { zračenjem }\end{array}$} & & \\
\hline & M & SD & M & SD & & \\
\hline Kvaliteta života & 3,03 & 0,9 & 3,40 & 0,8 & $-1,592$ & 0,117 \\
\hline Zadovoljstvo zdravljem & 2,83 & 0,9 & 3,46 & 0,8 & $-2,828$ & 0,007 \\
\hline
\end{tabular}

Usporedba ocjene KŽ među ispitivanim skupinama u odnosu na spol pokazala je značajnu razliku.
Onkološki bolesnici muškog spola liječeni zračenjem statistički značajno većom ocjenom procjenjivali su svoju KŽ u odnosu na bolesnike muškog spola liječene kemoterapijom $(\mathrm{p}=0,037)$ (tablica 2$)$.

Tablica 2. Rezultati i prosječne vrijednosti ocjene $K \check{Z} i$ zadovoljstva zdravljem u onkoloških bolesnika, postignuti u upitniku WHOQOL-BREF u odnosu na spol

\begin{tabular}{|c|c|c|c|c|c|c|c|}
\hline \multirow{3}{*}{ Domena } & \multirow{3}{*}{ Spol } & \multicolumn{4}{|c|}{ Onkološki bolesnici } & \multirow{3}{*}{ t-test } & \multirow{3}{*}{$p$} \\
\hline & & \multicolumn{2}{|c|}{$\begin{array}{c}\text { Liječeni } \\
\text { kemoterapijom }\end{array}$} & \multicolumn{2}{|c|}{$\begin{array}{c}\text { Liječeni } \\
\text { zračenjem }\end{array}$} & & \\
\hline & & M & SD & $M$ & SD & & \\
\hline Kvaliteta & muškarci & 3,00 & 0,8 & 3,55 & 0,2 & $-2,166$ & 0,037 \\
\hline života & Žene & 3,10 & 1,2 & 3,16 & 0,7 & 0,147 & 0,885 \\
\hline Zadovoljstvo & muškarci & 2,90 & 0,9 & 3,44 & 0,8 & 1,963 & 0,057 \\
\hline zdravljem & Žene & 2,79 & 0,9 & 3,5 & 0,9 & 2,011 & 0,051 \\
\hline
\end{tabular}

Analizirana je korelacija između životne dobi ispitanika sa samoocjenom KŽ i zadovoljstva zdravljem. Nije se pokazala statistički značajna razlika između promatranih domena i životne dobi ispitanika (tablica 3).

Tablica 3. Povezanost procjene $K \check{Z} i$ zadovoljstva $z$ dravljem sa životnom dobi ispitanika

\begin{tabular}{ccc}
\hline \multirow{2}{*}{ Domene } & \multicolumn{2}{c}{ Životnadob } \\
\cline { 2 - 3 } & Spearman s rho & $\mathrm{p}$ \\
\hline Kvaliteta života & 0,217 & 0,095 \\
\hline Zadovoljstvo zdravljem & 0,082 & 0,535 \\
\hline
\end{tabular}

Raščlamba ocjene zadovoljstva zdravljem pokazala je značajnu razliku. Bolesnici s pozitivnim bračnim statusom liječeni zračenjem značajno većom ocjenom procjenjivali su svoje zadovoljstvo zdravljem u odnosu na bolesnike liječene kemoterapijom $s$ negativnim bračnim statusom $(\mathrm{p}=0,019)$ (tablica 4). 
Tablica 4. Rezultati i prosječne vrijednosti ocjene $K \check{Z}$ i zadovoljstva zdravljem u onkoloških bolesnika, postignuti u upitniku WHOQOL-BREF u odnosu na bračni status

\begin{tabular}{|c|c|c|c|c|c|c|c|}
\hline \multirow{3}{*}{ Domena } & \multirow{3}{*}{$\begin{array}{l}\text { Bračni } \\
\text { status }\end{array}$} & \multicolumn{4}{|c|}{ Onkološki bolesnici } & \multirow{3}{*}{ t-test } & \multirow{3}{*}{$p$} \\
\hline & & \multicolumn{2}{|c|}{$\begin{array}{c}\text { Liječeni kemotera- } \\
\text { pijom }\end{array}$} & \multicolumn{2}{|c|}{$\begin{array}{c}\text { Liječeni } \\
\text { zračenjem }\end{array}$} & & \\
\hline & & M & SD & M & SD & & \\
\hline \multirow{2}{*}{$\begin{array}{l}\text { Kvaliteta } \\
\text { života }\end{array}$} & pozitivan & 2,95 & 0,8 & 3,35 & 0,9 & 1,517 & 0,137 \\
\hline & negativan & 3,28 & 0,8 & 3,50 & 0,7 & 0,422 & 0,679 \\
\hline \multirow{2}{*}{$\begin{array}{c}\text { Zadovoljstvo } \\
\text { zdravljem }\end{array}$} & pozitivan & 2,78 & 0,9 & 3,45 & 0,8 & $-2,438$ & 0,019 \\
\hline & negativan & 3,10 & 0,8 & 3,50 & 0,8 & 1,213 & 0,244 \\
\hline
\end{tabular}

Procjena kvalitete života $u$ ispitanika po domenama upitnika WHOQOL-BREF

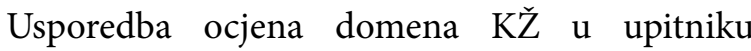
WHOQOL-BREFnije pokazala statistički značajnu razliku među ispitivanim skupinama (Tablica 5).

Tablica 5. Prosječne vrijednosti ocjene KŽ u onkoloških bolesnika postignute u upitniku WHOQOL-BREFpo domenama

\begin{tabular}{|c|c|c|c|c|c|c|}
\hline \multirow{3}{*}{ Domena } & \multicolumn{4}{|c|}{ Onkološki bolesnici } & \multirow{3}{*}{ t-test } & \multirow{3}{*}{$p$} \\
\hline & \multicolumn{2}{|c|}{$\begin{array}{c}\text { Liječeni kemotera- } \\
\text { pijom }\end{array}$} & \multicolumn{2}{|c|}{$\begin{array}{c}\text { Liječeni } \\
\text { zračenjem }\end{array}$} & & \\
\hline & M & SD & M & SD & & \\
\hline Tjelesno zdravlje & 62,7 & 12,6 & 64,4 & 12,9 & 0,548 & 0,586 \\
\hline Psihičko zdravlje & 68,8 & 10,6 & 69,3 & 13,0 & $-0,180$ & 0,857 \\
\hline Socijalni odnosi & 74,0 & 15,3 & 72,2 & 14,7 & 0,458 & 0,649 \\
\hline Okruženje & 54,0 & 9,6 & 56,7 & 10,5 & $-1,060$ & 0,294 \\
\hline
\end{tabular}

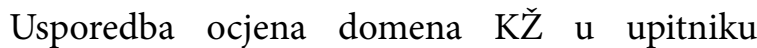
WHOQOL-BREF u odnosu na spol nije pokazala statistički značajnu razliku među ispitivanim skupinama (tablica 6).
Tablica 6. Prosječne vrijednosti ocjene KŽu onkoloških bolesnika postignute u upitniku WHOQOL-BREFpo domenama u odnosu na spol

\begin{tabular}{|c|c|c|c|c|c|c|c|}
\hline \multirow{3}{*}{ Domena } & \multirow{3}{*}{ Spol } & \multicolumn{4}{|c|}{ Onkološki bolesnici } & \multirow{3}{*}{ t-test } & \multirow{3}{*}{$p$} \\
\hline & & \multicolumn{2}{|c|}{$\begin{array}{c}\text { Liječeni } \\
\text { kemoterapijom }\end{array}$} & \multicolumn{2}{|c|}{$\begin{array}{l}\text { Liječeni } \\
\text { zračenjem }\end{array}$} & & \\
\hline & & M & SD & M & SD & & \\
\hline \multirow{2}{*}{$\begin{array}{l}\text { Tjelesno } \\
\text { zdravlje }\end{array}$} & muškarci & 63,1 & 12,0 & 66,1 & 9,2 & 0,869 & 0,391 \\
\hline & žene & 60,4 & 11,2 & 63,2 & 10,2 & 0,723 & 0,453 \\
\hline \multirow{2}{*}{$\begin{array}{l}\text { Psihičko } \\
\text { zdravlje }\end{array}$} & muškarci & 67,3 & 10,5 & 70,9 & 11,4 & $-1,004$ & 0,322 \\
\hline & Žene & 65,4 & 9,6 & 67,8 & 10,3 & $-0,923$ & 0,386 \\
\hline \multirow{2}{*}{$\begin{array}{l}\text { Socijalni } \\
\text { odnosi }\end{array}$} & muškarci & 72,6 & 16,0 & 72,2 & 15,5 & 0,086 & 0,932 \\
\hline & žene & 70,3 & 12,7 & 71,5 & 10,9 & 0,297 & 0,716 \\
\hline \multirow{2}{*}{ Okruženje } & muškarci & 53,6 & 9,3 & 58,3 & 8,3 & $-1,590$ & 0,191 \\
\hline & Žene & 52,0 & 8,4 & 55,6 & 9,1 & $-1,238$ & 0,239 \\
\hline
\end{tabular}

Analizirana je korelacija između rezultata domena KŽ u upitniku WHOQOL-BREF sa životnom dobi ispitanika. Nije se pokazala statistički značajna razlika između promatranih domena i životne dobi ispitanika (tablica 7).

Tablica 7. Povezanost procjene domene KŽ u upitniku WHOQOL-BREF sa životnom dobi ispitanika

\begin{tabular}{lcc}
\hline \multirow{2}{*}{ Domene } & \multicolumn{2}{c}{ Životnadob } \\
\cline { 2 - 3 } & Spearman's rho & $p$ \\
\hline Tjelesno zdravlje & 0,077 & 0,558 \\
\hline Psihičko zdravlje & 0,143 & 0,274 \\
\hline Socijalni odnosi & 0,102 & 0,437 \\
\hline Okruženje & 0,180 & 0,168 \\
\hline
\end{tabular}

Usporedba ocjena domena KŽ u upitniku WHOQOL-BREF u odnosu na njihov bračni status nije pokazala statistički značajnu razliku među ispitivanim skupinama (tablica 8 ). 
Tablica 8. Prosječne vrijednosti ocjene KŽ u onkoloških bolesnika postignute u upitniku WHOQOL-BREFpo domenama u odnosu na bračni status

\begin{tabular}{|c|c|c|c|c|c|c|c|}
\hline \multirow{3}{*}{ Domena } & \multirow{3}{*}{$\begin{array}{l}\text { Bračni } \\
\text { status }\end{array}$} & \multicolumn{4}{|c|}{ Onkološki bolesnici } & \multirow{3}{*}{ t-test } & \multirow{3}{*}{$p$} \\
\hline & & \multicolumn{2}{|c|}{$\begin{array}{c}\text { Liječeni } \\
\text { kemoterapijom }\end{array}$} & \multicolumn{2}{|c|}{$\begin{array}{l}\text { Liječeni } \\
\text { zračenjem }\end{array}$} & & \\
\hline & & M & SD & M & SD & & \\
\hline \multirow{2}{*}{$\begin{array}{l}\text { Tjelesno } \\
\text { zdravlje }\end{array}$} & pozitivan & 63,3 & 12,7 & 63,7 & 14,8 & 0,087 & 0,931 \\
\hline & negativan & 62,4 & 10,1 & 61,8 & 10,7 & 0,123 & 0,876 \\
\hline \multirow{2}{*}{$\begin{array}{l}\text { Psihičko } \\
\text { zdravlje }\end{array}$} & pozitivan & 70,4 & 9,5 & 68,8 & 14,5 & 0,436 & 0,660 \\
\hline & negativan & 68,3 & 8,8 & 67,2 & 11,2 & 0,357 & 0,720 \\
\hline \multirow{2}{*}{$\begin{array}{l}\text { Socijalni } \\
\text { odnosi }\end{array}$} & pozitivan & 76,5 & 14,3 & 72,0 & 15,0 & 1,005 & 0,321 \\
\hline & negativan & 74,7 & 10,9 & 72,4 & 11,8 & 0,889 & 0,403 \\
\hline \multirow{2}{*}{ Okruženje } & pozitivan & 55,1 & 9,1 & 57,7 & 10,7 & 0,867 & 0,391 \\
\hline & negativan & 55,1 & 9,1 & 57,7 & 10,7 & 0,867 & 0,391 \\
\hline
\end{tabular}

\section{Procjena psihičkih simptoma mjerena upitni- kom SCL-90}

U prvoj fazi obrade prikupljenih rezultata istraživanja sistematizirani su osnovni statistički parametri za svaku ispitivanu varijablu cjelokupnog uzorka ispitanika. Kada se utvrdilo da je svaka pojedinačna varijabla normalno distribuirana (Kolmogorov-Smirnovljevim testom) mogao se primijeniti Studentov t-test za testiranje značajnosti razlika između dvije aritmetičke sredine.

Usporedbom pojave psihičkih simptoma među ispitivanim skupinama pokazala se statistički značajna razlika. Naime bolesnici liječeni kemoterapijom pokazali su statistički značajno veću izraženost simptoma somatizacije $(\mathrm{p}=0,037)$, interpersonalne vulnerabilnosti $(p<0,05)$, fobije $(p<0,05)$ i nespecifičnih simptoma $(\mathrm{p}<0,05) \mathrm{u}$ odnosu na bolesnike liječene zračenjem (tablica 9).
Tablica 9. Usporedba učestalosti psihičkih simptoma mjerenih SCL-90 upitnikom u onkoloških bolesnika

\begin{tabular}{|c|c|c|c|c|c|c|}
\hline \multirow{3}{*}{ Varijabla } & \multicolumn{4}{|c|}{ Onkološki bolesnici } & \multirow{3}{*}{$\mathrm{t}$} & \multirow{3}{*}{$p$} \\
\hline & \multicolumn{2}{|c|}{$\begin{array}{c}\text { Liječeni } \\
\text { kemoterapijom }\end{array}$} & \multicolumn{2}{|c|}{$\begin{array}{c}\text { Liječeni } \\
\text { zračenjem }\end{array}$} & & \\
\hline & $M^{*}$ & $\mathrm{SD}^{*}$ & M & SD & & \\
\hline Somatizacija & 0,80 & 0,47 & 0,63 & 0,42 & 2,110 & 0,037 \\
\hline Opsesivno & & & & & & \\
\hline kompulzivni & 0,93 & 0,53 & 0,87 & 0,49 & 0,752 & 0,453 \\
\hline simptomi & & & & & & \\
\hline $\begin{array}{l}\text { Interpersonalna } \\
\text { vulnerabilnost }\end{array}$ & 0,82 & 0,49 & 0,32 & 0,28 & 8,007 & $<0,05$ \\
\hline Depresija & 0,90 & 0,56 & 0,86 & 0,48 & 0,431 & 0,667 \\
\hline Anksioznost & 0,88 & 0,51 & 0,86 & 0,50 & 0,169 & 0,866 \\
\hline Agresivnost & 0,60 & 0,47 & 0,60 & 0,46 & 0,015 & 0,988 \\
\hline Fobije & 0,63 & 0,51 & 0,20 & 0,26 & 6,807 & $<0,05$ \\
\hline Paranoidne ideje & 0,75 & 0,51 & 0,70 & 0,50 & 0,617 & 0,538 \\
\hline Psihotična obilježja & 0,45 & 0,41 & 0,48 & 0,43 & 0,552 & 0,581 \\
\hline $\begin{array}{l}\text { Nespecifični } \\
\text { simptomi }\end{array}$ & 1,00 & 0,53 & 0,43 & 0,29 & 8,493 & $<0,05$ \\
\hline
\end{tabular}

\section{RASPRAVA}

Onkološki bolesnici osjetljiva su skupina bolesnika. Njihovi životi i životi članova njihovih obitelji bitno su poremećeni u odnosu na ustaljeno izvršavanje svakodnevnih obveza. Svaka je osoba individua za sebe, na različite se načine nosi s dijagnozom karcinoma i na različite načine pokazuje ili ne pokazuje svoje emocije.

Ovaj rad je obuhvatio istraživanje KŽ i pojavnosti psihičkih simptoma u onkoloških bolesnika. Rezultati subjektivne procjene $\mathrm{KZ}$ dobiveni u provedenom istraživanju pokazuju da postoji značajna razlika u KŽ ispitanika, kao i razlika između ispitanika s obzirom na vrstu onkološkog pristupa u liječenju. Ocjena zadovoljstva zdravljem pokazala je značajnu razliku među ispitanicima u odnosu na vrstu onkološkog pristupa u njihovom liječenju. Bolesnici liječeni zračenjem statistički značajno većom ocjenom su procijenili svoje zadovoljstvo zdravljem $\mathrm{u}$ odnosu na bolesnike liječene kemoterapijom. Također, pokazala se značajno veća pojavnost psihičkih simptoma u bolesnika liječenih zračenjem u odnosu na bolesnike liječene kemoterapijom. Mehanizam 
djelovanja citostatika još uvijek nije do kraja razjašnjen, ali postoje istraživanja o nuspojavama. Važno je njihovo djelovanje na probavni sustav, jer on je osnova za održavanje ravnoteže elektrolita i unosa hranjivih tvari u organizam. Ta ravnoteža može biti poremećena uslijed mučnine, povraćanja, proljeva, opstipacije, smanjenog apetita, promjena u okusu i sl. Nuspojave poput alopecije, velikog gubitka tjelesne težine, ožiljaka i hematoma na mjestima primjene kemoterapije, za neke bolesnike predstavlja biljeg koji ih izdvaja u društvu. Neželjene posljedice kemoterapije poput mučnine, povraćanja i proljeva mogu pridonijeti pojavnosti psihičkih simptoma. Oni se također povezuju i s anemijom i nakupljanjem nusprodukata razorenih tumorskih stanica. Kemoterapijski lijekovi koji prolaze krvno moždanu barijeru mogu uzrokovati neurološku toksičnost koja uzrokuje umor (8). Baum i suradnici u svom istraživanju KŽ u žena oboljelih od raka dojke navode da toksične nuspojave kemoterapije mogu biti toliko averzivne da pacijentice vjeruju da su nuspojave gore od raka (9). Mnoga istraživanja ukazuju na to da pacijenti pate od značajne i dugoročne psihološke boli kao posljedica liječenja raka. Andrews navodi u svojoj studij, da je $33 \%$ bolesnika s dijagnozom raka iskusilo psihološku bol, a do 70 \% njih iskusilo je neki stupanj tjeskobe i depresije (10). Potvrđeno je da se kod $25 \%$, a po nekim istraživanjima čak i do $50 \%$ bolesnika liječenih kemoterapijom javlja ozbiljna psihopatološka reakcija kod koje ne može doći do poboljšanja bez psihološke ili psihijatrijske intervencije (11). Bez obzira na liječenje, promjene fizičkog i emocionalnog integriteta nemir, bol, promjene izgleda, ovisnost i gubitak samopouzdanja iskazuju se kod tih pojedinaca, s posljedicom smanjenja KŽ u kratkom vremenu. Također, usporedba ocjene $\mathrm{KZZ} \mathrm{među} \mathrm{ispitivanim} \mathrm{skupinama} \mathrm{u} \mathrm{odnosu}$ na spol pokazala je značajnu razliku. Onkološki bolesnici muškog spola liječeni zračenjem statistički značajno većom ocjenom procjenjuju svoju $\mathrm{KŽ} \mathrm{u}$ odnosu na bolesnike muškog spola liječene kemoterapijom.

Muškarci su boljim ocijenili svoje zadovoljstvo opće zdravstvenim stanjem i KŽ u odnosu na žene s malignim oboljenjem. Slični rezultati dobiveni su $\mathrm{u}$ istraživanjima Hjermstad i suradnici i Schwartz i suradnici $(12,13)$. U istraživanju Mosconia i suradnika žene s rakom dojke imale su lošiju tjelesnu i poslovnu aktivnost od ispitanika s rakom debelog crijeva i od žena bez oboljenja, dok su drugom istraživanju žene oboljele od raka grla procijenile svoju KŽ boljom od opće populacije. Općenito se moglo zaključiti da su KŽ visokom procijenile osobe koje nisu trebale kemoterapiju (14). Salonen i suradnici navode da su žene koje nisu primale kemoterapiju niti hormonalnu terapiju imale manji rizik od narušavanja slike o tijelu za razliku od žena koju su bile podvrgnute tim terapijama (15). U većini studija prikazane su značajne tjelesne, psihološke i socijalne teškoće takvih žena, međutim ne u svima, iz čega se može zaključiti da faktori kao što su vrsta tretmana, socioekonomski faktori, socijalna podrška, dostupnost podrške iz okoline i sl. utječu na razlike u dobivenim rezultatima. Stoga je potrebno više istraživanja kojima bi se izdvojila važna područja koja razlikuju skupine ispitanika.

Bračni status nije pokazao značajniju povezanost sa $\mathrm{KŽ} \mathrm{u} \mathrm{ispitanika.}$

Rezultati istraživanja koje je provedeno na velikoj skupini australskih žena, tri i dvanaest mjeseci nakon operacije raka dojke u ranoj fazi, pokazuju kako se utjecaj bolesti i liječenja na KŽ razlikovao prema dobi, obrazovanju i bračnom statusu. Neudane žene i one s nižim stupnjem obrazovanja niže su procijenile $K Z \check{~ u ~ v e c ́ e m ~ b r o j u ~ p o d r u c ̌ j a ~ K Z ̌ ~(16) . ~}$

$\mathrm{KŽ} \mathrm{bi} \mathrm{trebala} \mathrm{postati} \mathrm{indikator} \mathrm{uspješnosti} \mathrm{mul-}$ tidisciplinarnog tretmana i ukazivati na područja u kojima je oboljeloj osobi potrebna podrška. Iako veličina uzorka ne dozvoljava generalizaciju ovih rezultata, dobiveni rezultati ukazuju na procijenjenu zadovoljavajuću opću KŽ oboljelih od malignih bolesti. Potrebno je naglasiti da su u ovom istraživanju obuhvaćene samo neke varijable koje imaju utjecaj na KŽ (spol i dob). Zbog osjetljivog i kompleksnog područja, u daljnjim istraživanjima KŽ oboljelih od malignih bolesti bilo bi vrijedno kontrolirati i varijable poput vrste bolesti, stručne spreme, vremena od postavljene dijagnoze, psihosocijalne podrške, načina suočavanja s bolešću, seksualnost/intimnost. Isto tako bilo bi korisno što više oboljelih obuhvatiti 
programima psihosocijalne podrške i utvrditi njihovu učinkovitost kako ukazuju navodi svjetske literature.

KŽ temeljena na zdravlju osoba s malignom bolesti mora biti cilj i krajnji ishod terapijskog i rehabilitacijskog procesa za svakog bolesnika s malignom bolesti.

\section{ZAKLJUČAK}

Onkološki bolesnici liječeni zračenjem statistički značajno većom ocjenom su procjenjivali svoje zadovoljstvo zdravljem i imali su manju učestalost psihičkih simptoma u odnosu na bolesnike liječene kemoterapijom.

\section{LITERATURA}

1. Braš M. Epidemiologija i kliničke slike najčešćih psihijatrijskih poremećaja u onkologiji. U: Gregurek R, Braš M, ur. Psihoonkologija. Osijek: Grafika d.o.o. 2008;51-78.

2. Gregurek R, Braš M. Uvod. U: Gregurek R, Braš M, ur. Psihoonkologija. Osijek: Grafika Osijek 2008;12-3.

3. Prlić N. Quality of life in post-stroke patients: self-evaluation of physical and mental health during six months. Acta Clin Croat 2012;519.

4. Pereira LJ, Caputo JB, Castelo PM, Andrade EF, Marques LS, Paiva SM, Pereira SM, Pereira CV. Oral physiology and quality of life in cancer patients. Nutr Hasp 2015; 31:2161-6.

5. Barre VP, Padmaja G, Saxena RK, Rana S. Impact of Medical Intervention on Stress and Quality of Life in Patients whit Cancer. Indian J Palliat Care 2015;21:203-8.

6. Pibernik-Okanović M. Psychometric properties of theWorld Health Organisation quality of life questionnaire (WHOQOL-100) in diabetic patients in Croatia.Diabetes Res Clin Pract 2001;51:133-43.

7. Derogatis LR, Savitz KL. The SCL-90-R and the Brief Symptom Inventory (BSI) in Primary Care In. ME. Maruish, ur. Handbook of psychological assessment in primary care settings, Volume Mahwah, NJ: Lawrence Erlbaum Associates 2000;297-334.

8. Stasi R, Abriani L, Beccaglia P, Terzoli E, Amadori S. Cancer related fatigue: evolving concepts in evaluation and treatment. Cancer 2003;98:1786-801.

9. Baum, A., Revenson, T. A. i Singer, J. E. Handbook of health psychology. Manwah, New Yersey: Lawrence Erlabaum Associates 2001;2:4-27.

10. Andrews L. Systematic review summary Psychosocial interventions to improve quality of life and emotional well-being for recently diagnosed cancer patients. Singapore Nursing Journal 2013;40-3.

11. Bottomley A, Flechtner H, Efficace F, Vanvoorden V, Coens $C$, Therasse P. Health related quality of life outcomes in cancer clinical trials. Eur J Cancer 2005;41:1697-709.

12. Hjermstad, et al. Health-related quality of life in the general Norwegian population assessed by the European Organization for Research and Treatment of Cancer Core Quality-of-Life Questionnaire: The QLQ-C30 (+3). J Clin Oncol 1998;/16:/1188-96.

13. Schwarz, R., Hinz, A. Reference data for the quality of life questionnaire EORTC QLQ-C30 in the general German population. Eur J Cancer 2001;37:1345-51.

14. Cook Gotay, C., Muraoka, M. Y. (1998). Quality of Life in Long-Term Survivors of Adult-Onset Cancers. Journal of the National Cancer Institute, Vol. 90, No. 9, May 6, 1998.

15. Mosconi, P.et al. Quality of life in breast and colon cancer long-term survivors: an assessment with the EORTC QLQ-C30 and SF-36 questionnaires. Tumors 2002;88:110-6.

16. Salonen, P, Kellokumpu L, Tarkka PL, Koivisto $\mathrm{M}$, Kaunonen $\mathrm{M}$. Changes in quality of life in patients with breast cancer. Journal of Clinical Nursing 2010;20:255-66. 


\title{
A COMPARISON OF QUALITY OF LIFE AND PSYCHOLOGICAL SYMPTOMS IN ONCOLOGY PATIENTS TREATED WITH CHEMOTHERAPY AND RADIATION
}

\author{
Maria Bačić, Dragan Babić, Marko Pavlović \\ Faculty of Health Studies, University of Mostar, Bosnia and Herzegovina
}

\begin{abstract}
INTRODUCTION: Due to its severity cancer is a disease that has a powerful effect on the psychological condition of the patient. Despite great advancements in the treatment of malignant diseases, the quality of life is negatively affected by the course of disease, its treatment and psychological challenges of the disease.

OBJECTIVE: Determine the quality of life and the profile of psychological symptoms in oncology patients and determine whether the quality of life and the profile of psychological symptoms differentiate between oncology patients treated with chemotherapy and those treated with radiation.

SUBJECTS AND METHODS: The study was conducted at the Department of Oncology of the University Clinical Hospital Mostar. The study included 60 patients who underwent chemotherapy and radiotherapy treatments. Quality of Life Scale (WHOQOL-BRE) of the World Health Organization was used to measure the quality of life. The Symptom Checklist90(SCL-90-R)was used for assessment of psychological symptoms.

RESULTS: $63.3 \%$ of patients were men and $36.7 \%$ of patients were women. The youngest patient was 27 years old and the oldest 77 years old. Patients treated with radiation assessed their satisfaction with health with a significantly higher score as opposed to patients treated with chemotherapy $(\mathrm{p}=0.007)$. Male oncology patients treated with radiation assessed their quality of life with a significantly higher score $(\mathrm{p}=0.037)$. Patients with a positive marital status who were treated with radiation assessed their satisfaction with health with a significantly higher score $(\mathrm{p}=0.019)$. Patients treated with chemotherapy showed significantly higher levels of somatization symptoms $(\mathrm{p}=0.037)$, interpersonal vulnerability $(\mathrm{p}<0.05)$, phobia $(\mathrm{p}<0.05)$, and nonspecific problems $(\mathrm{p}<0.05)$ in relation to patients treated with radiation.

CONCLUSION: Oncology patients treated with radiation assessed their satisfaction with health with a significantly higher score and had a lower incidence of psychological symptoms in relation to patients treated with chemotherapy.
\end{abstract}

Key words: quality of life, psychological symptoms, oncological patients

Correspondence:

Maria Bačić

E-mail: maria.bacic1993@gmail.com 